\title{
Klimaets plass i norsk historie En forskningshistorisk oversikt
}

\author{
EINAR SOLHEIM PEDERSEN
}

Pedersen, E. S. 2015. Climate in Norwegian history. A research historical overview. AmS-Varia 58, 61-76, Stavanger. ISSN 0332-6306, ISBN 978-82-7760-167-0

Based on the threatening climatic situation confronting the world and the fact that Norway's geographical position makes the country vulnerable to climate change, this article addresses the paradox that climate has only interested Norwegian historians to a negligible extent. In a historiographical analysis, a review is made of Norwegian historical research over the last 100 years to establish what place climatic effect and climate change has had on Norwegian historical development. The seeming lack of interest for the subject is contrasted with the opposite international situation and the situation in other relevant subject areas. Characteristically, the degree to which Norwegian historians have been engaged in interdisciplinary cooperation has been small. The starting point has been the firm belief that more knowledge about climate and climate change can contribute significantly to a better understanding of historical development in Norway. It is also argued that, because of this, historians have lost an opportunity to extend the possibilities of coping with the climatic challenges facing society.

Einar Solheim Pedersen, Museum of Archaeology, University of Stavanger, NO-4036 STAVANGER, NORWAY. Phone: (+47) 518326 58. E-mail: einar.s.pedersen@uis.no

Key Words: climate, climatic development, climate change, Norwegian history, research history, international research, interdisciplinarity

\section{Klimatrusselen}

Hva som kommer til å skje med klimaet, er den viktigste enkeltsaken for livet på jorden i tiden som ligger foran oss. Helt uavhengig av om en tror den globale oppvarmingen er delvis menneskeskapt eller ikke, vil endringer i temperaturforholdene, havstiging, skiftinger i havstrømmenes løp, for å nevne noen mulige konsekvenser, fundamentalt forstyrre de naturgitte rammene en har vendt seg til de siste hundreårene. All erfaring med klimaet før oss tilsier at endringene skjer over kort tid, og virkningene kan dermed bli dramatiske. Lite tyder på at verdens politiske ledere klarer å bli enige om substansielle reduksjoner i utslippet av klimagasser.

\section{Problemstillinger}

De naturlige omgivelsene, inkludert klimaet, har alltid satt begrensinger og gitt rammer for den menneskelige utfoldelsen. De skriftlige kildene er fulle av beretninger om hvordan naturen og de naturlige ytringene har dirigert menneskenes handlemåter. De utallige værmerkene som har levd blant folk langt tilbake i tid, forteller at det å forutsi været har vært viktig, og at det oftere er blitt gjort med en følelse av frykt enn med forventninger om at noe positivt skulle inntreffe.

Den mer faglige rettete interessen for naturen og klimaet går også langt tilbake i tid. Beretninger finnes både fra antikken og middelalderen, særlig om hva ulike klimakatastrofer har ført til av menneskelig lidelse. Geografen Mike Hulme (2009) slår fast at en allerede i opplysningstiden ble klar over at menneskelige handlinger kunne endre klimaet, og utover på 1800-tallet ble naturlige klimasvingninger i økende grad undersøkt og dokumentert (Hulme 2009:38 ff., 68). Fra 1950-årene begynte klimaendringene å bli ansett som farlige, men ble ikke hevet opp til et internasjonalt nivå før på FN-konferansen om miljø og utvikling i 1992 som ledet til rammekonvensjonen om klimaendring (Hulme 2009:191).

Hovedsiktepunktet med denne artikkelen er, på denne bakgrunnen, å undersøke hvorfor norske historikere, med få unntak, har lagt liten vekt på, eller fullstendig 
ignorert, klimaets betydning for den historiske utviklingen i Norge. Dette utgangspunktet hviler på en grunnleggende oppfatning om at klimaendringer og -variasjoner er elementer som fortjener en større plass i norsk historisk forskning. Artikkelen vil også forsøke å gi svar på hvorfor klimaet er tillagt så liten vekt i forskningen, og det kan innledningsvis antydes at de viktigste årsakene er historikernes manglende tillit til egne data, redsel for klimadeterminisme og deres manglende interesse for tverrvitenskapelig samarbeid.

\section{Klimaet i norsk historieforskning - første fase}

Selv om flere har påstått (bl.a. Ljungquist 2009:10) at en først på 1990-tallet innså at klimaet hadde variert siden istiden, så kan det ikke herske tvil om at klimaendringer lenge har vært tema i norsk historieforskning. Ludvig Daae (1868) var tidlig ute, men det ble aktuelt med større tyngde fra begynnelsen av 1900-tallet, riktignok sporadisk. Som nevnt innledningsvis vil jeg gå gjennom norsk historieforskning og -skriving for å bringe på det rene holdningen til klimaets betydning for den historiske utviklingen. Jeg vil også forsøke å analysere hvorfor norske historikere tilsynelatende i så liten grad har brydd seg om klimaendringer som årsaksfaktor. Selv etter at klimaendringene for fullt er satt på den politiske dagsorden, har ikke norske historikere lagt økt vekt på temaet i sin forskning. I de fleste fag innen natur- og samfunnsvitenskapene er klima et stort forskningstema, og det har også blitt det innen enkelte humanistiske fag, som for eksempel arkeologi.

Edvard Bull (1913) publiserer i 1913 en artikkel i tidsskriftet Samtiden, Klima og historie, som har preg av å være et program. Han skisserer en utdyping av Karl Marx' materialistiske historieoppfatning for historieskrivingen, og denne utdypingen hentes primært fra naturfagene. Han trekker fram den betydningen de naturlige omgivelsene har hatt for menneskeheten, og han konsentrerer seg særlig om de klimatiske forholdene. Han er inspirert av forskningen til den amerikanske geografen Ellsworth Huntington (1913) som fant «pulsslag» i klimaet, slag som tar generasjoner mellom hver gang de gjentar seg og som får store utslag for økonomi og samfunnsliv. Bull har også satt seg inn i den tysk/østerrikske klimatologen Eduard Brückners (1890) teorier med hans 35-årige klimasykler som ble implementert på samfunnsmessige endringer. Bull var opptatt av den svenske kjemikeren og oseanografen Otto Pettersson (1913) som hadde lagt fram en sammenhengende teori om klimaskifte i VestEuropa i det 14. århundre. Hans viktigste funn var at klimaet ikke ble kaldere og våtere, men mer uregelmessig med voldsomme stormer, uvær og oversvømmelser som ble verre jo lenger nord en kom. Derfor ble Norge og Island hardere rammet enn Danmark og Sverige. Bull har ikke noe faglig materiale å bidra med selv, han lanserer en forklaringsmodell for analyse av historien som er basert på en økt forståelse av «naturens egen ubrytelige gang» (Bull 1913:208). Hensikten hans er klart å utvide det marxistiske grunnlaget for tolking av samfunnsmessig endring, «at søke «de sidste aarsaker» i produktions- og omsætningsformernes utvikling» (Bull 2013:200). Han ville legge kunnskap fra naturvitenskapene inn i det marxistiske analyseapparatet for å få et mer slagkraftig grunnlag for utarbeiding av samfunnsteori, også innen historiefaget.

Bull (1915-16) legger i 1916 fram mer konkret materiale enn han gjorde i 1913. Han tar utgangspunkt i en kritikk av Pettersson fra den islandske geologen Thorvaldur Thoroddsen (1913-14). Med basis i lesing av sagalitteraturen argumenterer Thoroddsen mot at det hadde vært vesentlige klimaendringer i Island i vikingtid og tidlig middelalder. Bull avviser sagaene som kilde til pålitelig kunnskap og trekker dessuten fram at korndyrkingen forsvant på Island, at islendingene ikke lenger spilte noen rolle i handelsvirksomheten, at dyreholdet helt skiftet karakter og understreker også tidspunkt for forekomsten av drivis rundt Island. I tillegg lister han opp at det i tidsrommet 1291 til 1392 nesten årlig inntraff hendelser som kan tolkes i lys av forverrete værforhold.

Innholdet i disse innledende merknadene er symptomatisk for vinklingen den internasjonale klimaforskningen har hatt fram til vår tid. Det er naturvitere som har interessert seg for klimaendringer. Når de har ønsket å rekonstruere klimaet i forhistorisk og historisk tid, har de brukt arkeologiske og historiske data til å bygge opp under sine teorier om ulike klimautslag. Det dreier seg særlig om temperatur- og nedbørsforhold og om vindsirkulasjonsmønstre. Tidligere var en også interessert i historiske proksydata, dvs. data som kan gi indirekte informasjon om klimaet, slik som forekomst av uår, skipsforlis, avlingsstørrelse. I de siste tiårene har en hatt tilgang til andre data som til en viss grad har redusert betydningen av historiske klimadata. Her peker isboringene på Grønland seg ut som en vesentlig kilde, i tillegg til økt kunnskap om klimafenomener en kan føre bakover i tid som for eksempel El Niño-problematikken eller utvikling av metoder som dendrokronologi og innen bre- og skoggrenseforskningen. Det har vært viktig at dateringsmetodene er blitt mer nøyaktige med oppfinningen og de stadige forbedringene av ${ }^{14} \mathrm{C}$-metoden samt andre metoder som gir dateringer med etter hvert små standardavvik. Dette er særlig relevant i historisk tid, 
der det kreves at dateringene er svært nøyaktige for at de skal ha fullgod verdi.

På denne tiden var klimaforskningen i sin begynnelse, og Brückner, Huntington o.a. var blant pionerene. En må huske at erkjennelsen av at det hadde vært istider og klimavariasjoner bare var noen tiår gammel, og det bærer da også forskningen preg av. Edvard Bull var forut for sin tid. Han grep fatt i problemstillinger som var relevante for forståelsen av norsk historie, og det var flukt over den måten han satte klimaelementet inn i sin historiske tenkemåte. Han fulgte imidlertid ikke opp det som i 1913 hadde sett ut som et program, og hans forsøk på en mer praktisk rettet forskningsinnsats på området, den lille artikkelen i Geografisk Tidsskrift fra 1916, er for lite bearbeidet.

\section{Klimaet i norsk historieforskning - andre fase}

Midt på 1920-tallet blir det fornyet interesse for klimaet som faktor i forståelsen av viktige sider av norsk historie. Det starter med artikler av to naturvitere, geologen og geografen Werner Werenskiold (1924) og meteorologen Anton Røstad (1924a), der klimaets betydning for nedgangstiden på 1300-tallet er tema. De har i stor grad samme referanseramme, de henviser til Huntington, Pettersson, Bull, Thoroddsen og også andre, og de spenner opp et bredt lerret med omtale av klimaforskning fra store deler av verden, inkludert historiske data fra hele Europa. De er enige om at mye tyder på en klimatisk forverring på 1300-tallet, men er uenige om graden av viktighet, der Werenskiold $(1924: 157,158)$ avviser at klimaforverringen skal ha hatt en negativ virkning for den generelle historiske utviklingen.

Sigvald Hasund (1924) tar opp tråden fra Røstads artikkel og medgir at det er tilstrekkelig datagrunnlag til å kunne si at det var en klimaforverring fra slutten av 1200-tallet og utover på 1300-tallet (Hasund 1924:289). Likevel mener han at det ikke er en tydelig sammenheng mellom den generelle nedgangen og klimaforverringen (Hasund 1924:290). Han er usikker på overføringsverdien av at det er påvist klimatiske kriseår på kontinentet, i England og rundt Østersjøen. Konklusjonen hans er at det var svartedauden som førte til økonomiske nedgangstider og ikke klimaet.

Røstad tar også opp skjebnen til den norrøne bosetningen på Grønland og skriver at det er pålitelige rapporter på at det kaldere klimaet i høgmiddelalderen førte til økt forekomst av drivis rundt Grønland, men han konkluderer med at bosetningen opphørte fordi den norrøne befolkningen ble drevet bort av eskimoene (Røstad 1924a:210). Hasund berører også den norrøne bosetningen på Grønland og er av samme oppfatning som Røstad. Bosetterne ble «tynt» av eskimoene, først Vestbygda på 1300-tallet og dernest Austbygda i 1418 (Hasund 1924:296). Samme år, i 1924, gir Oscar Albert Johnsen ut sin avhandling om Norgesveldets undergang (Johnsen 1924). Han har fått med seg Bulls artikkel fra 1913, der Bull med basis i bla. Huntington og Brückner hevder at klimavekslinger har vært betydelige og langvarige og har vært bestemmende for den historiske utviklingen (Johnsen 1924:5). Johnsens holdning til Bulls oppfatning er interessant fordi han formulerer de innvendingene som kommer til å gå igjen og igjen hos det store flertallet av historikere (Johnsen 1924:6). Johnsen mener at selv om det finnes klimadata så er de for få og ikke representative. Han finner klimateorien interessant, men en må overlate til senere forskning, både innen historie og naturfagene, å komme fram til avgjørende resultater. Historikerne må finne årsakene innen sitt primærmateriale; økonomiske, sosiale, politiske og kulturelle forhold.

Røstad (1924b) svarer Hasund med både å imøtegå Hasunds historiefaglige argumentasjon, dvs. tolkingen av de historiske kildene, bla. stiller han spørsmål ved at Hasund lager en motsetning mellom virkningen av svartedauden og klimautslag, og ikke minst gir han historikeren et stikk med følgende påpeking: «Men når ein historiegranskar vil døma um og slå vekk slike faktorar som innverknaden av eit klimat-umskifte, då må me kunna krevja at han byggjer domane sine på eit eksakt fysikalsk grunnlag» (Røstad 1924b:415). Den viktigste uenigheten mellom de to finnes i tolkingen av klimadata og klimavirkninger. Hvordan skal en gå fra konkrete data, meldinger om værets innvirkning på avlinger og ulike næringer generelt samt forsøk på å lage oversikter over for eksempel gardspriser og produksjonstall, til å skille klimaets betydning fra andre elementer som hadde betydning for folks levekår?

Hasund (1925) følger ikke opp Røstads noe konfronterende utsagn, men nøyer seg i sitt neste innlegg med å fastholde at han har ingenting mot nye teorier, for eksempel om klima, men han krever klarere bevis, spekulasjoner setter han seg imot. I dette innlegget forlater Hasund middelalderen og går framover i tid. Han trekker fram årene 1740-42 og 1771-73 som var perioder med dokumentert dårlig vær, uår og nedgang i folketallet. Dette setter han opp mot den generelle trenden på 1700-tallet som var positiv med økende folketall og økonomisk framgang og med stigende priser på garder og med nyrydding. Slik ville det ikke ha vært dersom værforholdene hadde slått så negativt ut. Han synes at «...desse klimatteoriane byggjer på laus grunn, kor rett sjølve byggverket enn kann vera» (Hasund 1925a:10). 
Diskusjonen tar nå en dreining, og årsaken til det er at Edvard Bull (Bull 1925) igjen melder seg på. Han flytter fokus til den norrøne bosetningen på Grønland og tar utgangspunkt i de arkeologiske utgravingene som den danske historikeren og arkeologen Poul Nørlund (1924) foretok på Herjolfsnes (Ikigait) helt sør på Grønland i 1921. På grunnlag av data fra utgravinger, foretatt på gravplassen på Herjolfsnes, fastslår Bull at det har vært varmere her på 1300-tallet enn det ble senere og mener således at det var en nedgang i temperaturen utover på 1400-tallet, noe som bidro til bosetningens undergang. Han trekker også fram det forholdet at en på Island sluttet å dyrke korn på 1300-tallet. Han avviser Hasunds påstand om at det ble lettere å kjøpe korn, og at det var dette som var bakgrunnen for at det ble slutt med dyrkingen. Bull tar også tak i Hasunds oppfatning av at det var svartedauden som var absolutt viktigste årsak til nedgangen i senmiddelalderen og argumenterer mot det ved å sammenligne utviklingen i Norge med andre land, der han mener at svartedauden alene ikke kan forklare at nedgangen i Norge ble så mye sterkere (Bull 1925:17, 18).

Rundt midten av 1920-tallet var dette et tema som fenget. I tillegg til de forfatterne som allerede er omtalt, var det bidrag fra flere andre. Professor i folkloristikk i Oslo, Reidar Th. Christensen (1925), og presten Torleif Homme (1925) hadde engasjerte innlegg, og i det danske tidsskriftet Naturens verden fulgte den kjente danske geologen V. Nordmann (1925) opp debatten som hadde gått i Norge. Fridtjof Nansen $(1925,1926)$ deltar også med to artikler. Nansen hadde kjennskap til M. Milancovic (1920) sitt grunnleggende arbeid om jordbanens presesjon, ekliptikk og eksentrisitet i forhold til solen som forklaring på klimaskiftene i kvartær tid. Jan Mangerud (1992a,b) gir en god forklaring på denne teorien.

Frode Fyllingsnes (1990) har i sin avhandling om de norrøne bygdene på Grønland en utmerket gjennomgang, atskillig mer detaljert enn min, av argumentene på alle sider i debatten som foregikk i 20-årene om klimaets betydning for bosetningen på Grønland (Fyllingsnes 1990:168,181). Hans konklusjon var at både de skriftlige og arkeologiske kildene var for mangelfulle til å kunne gi et klart svar på hvordan klimautviklingen hadde vært på Grønland i middelalderen, og at dersom en skulle komme videre måtte naturvitenskapene tas i bruk (Fyllingsnes 1990:181).

Imidlertid kom naturvitenskapene i stor grad til å være fraværende i arbeidet med å avdekke klimaets betydning for den historiske utviklingen. Dette er påfallende siden det var inspirasjonen fra naturvitere som Brückner, Huntington og Pettersson som hadde fătt Bull til å ta opp disse problemstillingene, og som han i stor grad støttet seg på i sin argumentasjon. Det kan nok ha virket fremmed at Bull åpenbart forsøkte både svært bevisst å inkludere naturgitte rammebetingelser $\mathrm{i}$ en historisk forklaringsmodell samt å gjøre de materielle, naturlige grunnforholdene til et konstitutivt ledd i den materialistiske historieoppfatningen, riktignok på et meget rudimentært nivå. Det er også karakteristisk for diskusjonen at den skriftlige empirien som ble framført var mangelfull rent kvantitativt, ofte analytisk tvetydig, og at utgangspunktet til historikere som Hasund og Johnsen var ubevegelig; klimaet var noe som hørte til på utsiden, det var økonomiske, sosiale og kulturelle tema historikere skulle beskjeftige seg med. Da Bull avsluttet sitt engasjement i temaet, var det heller ingen andre som fulgte opp.

Som et etterord til denne opphopingen av interesse for klimavirkningene kan nekrologen Halvdan Koht (1933) skrev etter Bulls død i 1932 trekkes fram. Han går gjennom Bulls virke som historiker og bruker mye plass på en omtale av Bulls arbeid med klimaets betydning $\mathrm{i}$ norsk historie (Koht 1933:150 - 151). Han understreker at Bull var den første som brakte temaet inn i historieforskningen, men ellers avviser han at klimaelementet hadde noe med den marxistiske tenkingen å gjøre. Han benekter også at klimaet hadde noen betydning for nedgangen i middelalderen, her må en finne svarene i de indre økonomiske og sosiale vilkårene. Koth mener at denne interessen hos Bull var et sidespor i hans forskningsinnsats, men dette synet reflekterer nok mer at Koth selv hadde ingen interesse eller forståelse for temaet. En nylesing av Bulls innlegg i denne saken tyder på at han har brukt mye tid på å sette seg inn i de naturvitenskapelige premissene for å forstå klimautviklingen. Hans fors $ø k$ på å gjøre klimaendringer til et tema i historieforskningen samt å inkludere klimaet som en naturgitt rammebetingelse i den materialistiske historieteorien, gir signaler om et intellektuelt og forskningsmessig løft som må ha vært krevende. At det ikke ble fulgt opp etter 1925, skyldes nok mer at Bulls politiske arbeid krevde for mye.

Edvard Bull var den sentrale personen bak Aschehougs andre norgeshistorie «Det norske folks liv og historie gjennem tidene» som kom ut 1929-1938. Han skrev selv bind 2 (Bull 1931). Her nevner han så vidt klimapåvirkninger (Bull 1931:158), men peker på at dette først blir aktuelt i andre halvpart av 1200-tallet, og at en da skal komme tilbake til temaet. Dette tyder på at han selv hadde tenkt å skrive bindet om den etterfølgende perioden, men han dør i 1932, og bindet kommer først ut i 1934, ført i pennen av Sigvald Hasund (Hasund 1934). Hasund hadde deltatt i debatten med Bull på 20-tallet, og i sitt bind drøfter han kort klimaets mulige betydning for 
nedgangen i senmiddelalderen. Han konkluderer med at omstendighetene synes å støtte teorien om en klimaforverring (Hasund 1934:148), men at det har vært vanskelig å føre bevis for at værlaget var verre i denne tiden enn ellers (Hasund 1934:149).

Norgeshistoriene som kommer med jevne mellomrom, kan ikke regnes som forskning, men stort sett har det vært de fremste historikerne i sine generasjoner som har bidratt, slik at en må regne med at de framstillingene som blir gitt oppsummerer forskningsstatus til enhver tid. Den delen av serien fra 1930-tallet som omhandler perioden fra 1500-tallet til ut på 1800-tallet skrives av Sverre Steen i fire bind (Steen 1930, 1932, 1933, 1935). Om disse fire bindene kan det kort sies at klimaet overhode ikke blir nevnt, noe som nok både avdekker Steens manglende interesse for emnet, men også at den generelle opptattheten av klimaet og de naturgitte rammebetingelsenes betydning for den historiske utviklingen var begrenset.

\section{Klimaforskningen $i$ etterkrigstiden - internasjonal satsing}

Etter krigen er Johan Schreiner den første til å trekke fram den mulige virkningen av klimaet. I sin avhandling (Schreiner 1949) «Pest og prisfall» siterer han Hasund fra hans bind i norgeshistorien samt Andreas Holmsen (1949), der de to sistnevnte er enige om at klimateorien ikke direkte kan bevises ut fra det historiske kildematerialet. De slår begge fast at enkelte ting kan tyde på at klimaet ble dårligere i løpet av 1300-tallet og at det holdt seg slik i et par hundre år (Holmsen 1949:421). Holmsen viser til årrings- og strandlinjeundersøkelser i Nord-Amerika, der det går fram at det var et varmt og tørt klima i perioden 1050-1300 og en betydelig økning i nedbør og nedgang i temperatur på 1300-tallet. Holmsen understreker at slike naturvitenskapelige undersøkelser ikke er utført i Norge eller i andre nord-europeiske land. Schreiner (1946-48:667-674) avrunder med å påpeke at problemet med å få utredet klimaets plass er blant de mest presserende i norsk historisk forskning, men at her kan historikerne selv ingenting utrette, og en må sette sin lit til dendrokronologi, pollenanalyse og studiet av leiravsetninger. Her viser han til botanikerne Ove Arbo Høeg (1944) og Knut Fægri (1945) og deres artikler i Viking, der det redegjøres for hvordan henholdsvis dendrokronologi og pollenanalyse kunne gi kunnskap om klimaforhold i tidligere tider.

Innen norsk historieforskning og -skriving er klimaspørsmålet ikke tema før Jørn Sandnes (Sandnes 1970) tar det opp og det store nordiske ødegårdsprosjektets norske del kommer i gang på begynnelsen av 1970-tallet.
Internasjonalt var imidlertid interessen for temaet sterkt stigende. Den tyske meteorologen/klimatologen Hermann Flohn skrev sine første artikler om klimaets betydning for mennesket allerede på 1940-tallet og utover på 1950- og 1960-tallet bidro han med utallige artikler og monografier. Den engelske meteorologen og klimatologen Hubert H. Lamb startet sin virksomhet på 1950-tallet og foretok en til da foreløpig oppsummering med tobindsverket «Climate. Present, Past and Future» (Lamb 1972, 1977). Dette er bare de mest framtredende i et etter hvert stort vitenskapelig miljø som var interessert i betydningen av klimaet for den forhistoriske og historiske utviklingen både globalt, regionalt og lokalt og som har etterlatt seg et enormt skriftlig materiale. Vanligvis var det forskere med naturvitenskapelig bakgrunn som var mest aktive, og disse hentet selv sine data fra skriftlige kilder.

I Norden skiller den svenske historikeren Gustaf Utterström seg ut. Han hadde økonomisk historie som spesialområde, men publiserte i 1955 en artikkel om klimafluktuasjoner (Utterström 1955). Han er godt opplest på de naturvitenskapelige klimateoriene og har dessuten oversikt over et stort tilfang av historisk kildemateriale, der vær og værforhold står sentralt. Hovedvekten i framstillingen ligger på svenske forhold, men han henter eksempler fra andre nordiske og europeiske områder. Han refererer den norske diskusjonen både på 1920-tallet og etter krigen og har satt seg inn klimaets betydning for utviklingen på Grønland og Island i seinmiddelalderen. Det interessante med Utterström er at han går ut over middelalderen og beskriver utviklingen i århundrene etter med særlig vekt på 1600-tallet. Han kjenner til «den lille istid» som ble lansert som vitenskapelig begrep så sent som i 1939(Utterström 1955:25) av geologen François E. Matthes (Matthes 1939:518-523). I sin framstilling trekker han på den naturvitenskapelige siden inn fag og metoder som bioklimatologi, dendrokronologi, fenologi, glasiologi, klimatologi, meteorologi, mikrobiologi, oseanografi, pollenanalyse, tefrakronologi og innen historie kildekategorier som avlingsstørrelse, temperaturvariasjoner, kornpriser, uår, sultkatastrofer, regnfrekvens- og mengde, befolkningsstatistikk og han rekonstruerer langtidstendenser innen klimautviklingen. Han påpeker at spesialiseringen blant vitenskapsfagene har ført til at historikerne har ignorert klimaendringene (Utterström 1955:25).

Utterströms konklusjon er at det er en sammenheng mellom klimaet og folks levekår (Utterström 1955:45-47). Han gjentar at historikernes konsentrasjon om økonomiske problemer, stagnasjon i befolkningstallene, sosiale opprør etc. har blendet for den betydningen 
naturkreftene har hatt for den historiske utviklingen (Utterström 1955:47) og forklarer dette med at historikere har hatt for liten kontakt med bl.a. meteorologer. Utterström var klart den historikeren som inntil dette tidspunktet hadde levert den best begrunnete og mest gjennomtenkte argumentasjonen for å ta med klimavirkninger inn i den historiske diskursen. Han avslutter med kritikk av uinteresserte historikere og understreking av nødvendigheten av å etablere samarbeid med naturvitenskapene.

\section{Klimaforskningen og ødegårdsprosjektet}

Jørn Sandnes tok opp klimaproblematikken på bred basis i sin doktoravhandling "Ødetid og gjenreising» (1971), og klima ble som nevnt tatt inn i den norske delen av det nordiske ødegårdsprosjektet. Sandnes ble knyttet til prosjektet i 1968 og ble leder for den norske delen i 1970. Prosjektet resulterte i en rekke punktundersøkelser, for det meste hovedoppgaver i historie, og klimavirkninger var ofte med blant de elementene en mente hadde hatt betydning for omfanget av ødelegging i ulike områder av landet.

Sandnes var påvirket av Holmsen som han også samarbeidet med i utformingen av retningslinjene for ødegårdsprosjektet. Det er nærliggende å tro at Sandnes hentet inspirasjon fra Holmsens, riktignok sparsomme, betraktninger rundt klimaproblematikken. Han viser til de tidligere norske diskusjonene rundt dette temaet (Sandnes 1971:235), og han refererer også til Lamb og Utterström, noe som antyder at han til en viss grad hadde fulgt med på den internasjonale forskningen. Sandnes slår fast at det var en klimaforverring i senmiddelalderen (Sandnes 1971:235), men argumenterer med at de historiske kildene ikke strekker til for å utdype dette nærmere, og at naturvitenskapene må gi svaret på spørsmålet om klimaforverring. Han mener det er vanskelig å vurdere holdbarheten og konsekvensene av de naturvitenskapelige undersøkelsene innen klimatologi, pollenanalyse og dendrokronologi som forelå på dette tidspunktet (Sandnes 1971:236). Han tar eksplisitt opp Utterströms artikkel i en note og kommer med følgende nedsabling: «Det må reises metodiske innvendinger mot den ukritiske sammenstilling av ulikeartet og ofte problematisk materiale som en kan finne brukt som grunnlag» (Sandnes 1971:235). Dette må i ettertid karakteriseres som en urettferdig og overflatisk karakteristikk av Utterströms artikkel.

Men verken Sandnes eller andre deltakere i ødegårdsprosjektet klarer likevel å gi helt slipp på den mulige forklaringsfaktoren som ligger i klimaskiftingene. Emnet tas opp i flere oversiktsartikler både i startfasen, underveis og i etterkant av prosjektet. Det dreier seg om behovet for bistand fra klimatologer og glasiologer (Holmsen \& Johannessen 1971:223-233), diskusjon av klimaets betydning sett $\mathrm{i}$ et regionalt perspektiv (Holmsen 1975:481-488) og bruk av klimastatistikk og behandling av fenomener som varmesum og teoretisk veksttid (Salvesen 1975:495, 496). Audun Dybdahl (1979) som fortsetter etter ødegårdsprosjektet å interessere seg for klimarelaterte problemstillinger, kommer i sin publikasjon om Stjørdalen inn på ulike metoder, deriblant iskjerneundersøkelsene på Grønland, for å avdekke omfanget av klimavirkninger (Dybdahl 1979:160 ff.), men konkluderer med at en må stille seg avventende til det foreligger en bedre faglig gjennomdrøfting av metodene (Dybdahl 1979:164). Sandnes selv tar på en grundig måte opp hvordan ulike naturvitenskapelige metoder kan bidra til å utfylle historiske data (Sandnes 1977:385-396). Han behandler dendrokronologi, pollenanalyse, fosfatundersøkelser, radiologiske dateringsmetoder og ${ }^{18} \mathrm{O}$-metoden fra iskjerneundersøkelsene på Grønland. Han er i utgangspunktet positiv, men konklusjonen blir likevel at nytten for historisk forskning innenfor klimaproblematikken er begrenset, og at det er behov for felles planlegging for å øke nytteverdien.

Det ble på 1970-tallet levert en rekke hovedfagsoppgaver innenfor rammen av ødegårdsprosjektet samt enkelte andre oppgaver med liknende problemstilling. Det var et ledd i «ødegårdsskjemaet» som studentene fulgte at klimavirkningene skulle vies noe plass. Det vanlige var at klimafaktoren så vidt ble nevnt med en konklusjon som gikk ut på at betydningen hadde vært liten, men noen ga denne problemstillingen større plass. Ødegårdsprosjektet ble formelt avsluttet i 1981, men i publikasjonen «Ødegårdstid i Norge» (Sandnes \& Salvesen 1978) oppsummerte Jørn Sandnes og Helge Salvesen erfaringene med prosjektet. Her kommer de også inn på hvilken plass klimaet fikk i de 24 undersøkelsene innenfor rammen av prosjektet og ti andre undersøkelser der temaene var beslektet. Det var et uttalt mål at en via botanisk kompetanse skulle få inn opplysninger om klimaendringer (Sandnes \& Salvesen 1978:28). Konklusjonen var at punktundersøkelsene ikke brakte inn noen ny informasjon om betydningen av klimaendringene, bortsett fra enkelte generelle data, hentet fra pollenanalyser og ${ }^{18} \mathrm{O}$-undersøkelser (Sandnes \& Salvesen 1978:167). Helge Salvesen går i en bosetningshistorisk studie (Salvesen 1979) fra Jemtland grundig gjennom de naturmessige rammene, inkludert ulike klimavirkninger, for jordbruksdrift. Han drøfter bonitet og jordarter (Salvesen 1979:34), de grunnleggende klimaforholdene og de rammene disse ga for jordbruksmessig utnytting (Salvesen 1979:36) og gir 
en beskrivelse av nedbør- og temperaturforhold (Salvesen 1979:40-42). Konklusjonen blir at klimaet ikke kan trekkes inn som årsak til endringer i driftsmåtene i jordbruket. En manglende utvidelse av åkerarealet hadde sosiale og økonomiske årsaker (Salvesen 1979:95-97, 173). Det framgår av argumentasjonen at den viktigste grunnen til avvisingen av at en klimaforverring hadde hatt betydning for utviklingen av jordbruket, var faren for å havne i klimadeterministiske tankebaner (Salvesen 1979:173).

Kjell Haarstad (1980) tar opp i en demografisk orientert artikkel, der utgangspunktet er en diskusjon av synspunktene til Malthus og Boserup, om årsakene til dødelighet i Trøndelag på 1700- og 1800-tallet kan være uår. Svaret hans på dette spørsmålet er bekreftende, men uårene blir i liten grad antatt å ha vært en følge av klimaforverring. I diskusjonen om grunnen til befolkningsveksten utover på 1800-tallet kan ha vært bedrete klimatiske forhold, svarer han klart at slik er det ikke (Haarstad 1980:16). Han mener at samfunnet på dette tidspunktet hadde funnet forsvarsmekanismer mot dødelighet forårsaket av klimaforhold.

\section{Den klimadeterministiske fellen}

Redselen for klimadeterminisme har vært dypt rotfestet blant historikere. De første naturviterne som begynte å interessere seg for klimavirkningene, slik som Huntington og senere også Lamb, ble betraktet som determinister. Den innflytelsesrike franske annalisten Emmanuel Le Roy Ladurie lister opp en mengde ulike data om klimapåvirkninger i sine to avhandlinger (Ladurie 1967, 1971) om historisk klimatologi, men ender opp med å avvise at klimaet har hatt vesentlig betydning for den historiske utviklingen selv om han gjør et unntak for de nordiske landene (Ladurie 1971:288, 292). Han trekker også fram klimadeterminismen som en felle for historikere (Ladurie 1971:17), noe som kan forklare at hans konklusjoner til dels står i motstrid til premissene, dvs. de helt overveldende bevisene på at klimaet har hatt forholdsvis stor betydning for folks liv gjennom tusen år. Laduries to avhandlinger kom like før ødegårdsprosjektet startet, og en må regne med at han ble lest av norske historikere selv om han i liten grad blir sitert. Dette kan ha vært en grunn til at klimaeffektene blir så overflatisk behandlet av de fleste som var involvert i ødegårdsprosjektet. I prosjektet var det ansatser til å ta klimavirkningene inn i den historiefaglige behandlingen av krisetiden i senmiddelalderen, og en erkjenner at klimaet tidvis var vesentlig dårligere og i realiteten var viktig for tilstanden i jordbruket, uten at en trekker noen konsekvenser av dette. Det er påfallende at en i liten grad bruker rene historiske kilder, men er svært opptatt av utsagnskraften til naturvitenskapelige data og metoder og så blir skuffet og avvisende når naturfagene ikke klarer å levere konkrete nok bevis på klimaets virkninger.

\section{Internasjonalt oppsving i klimaforskningen}

Avslutningsfasen av ødegårdsprosjektet faller i tid sammen med et oppsving i den internasjonale klimaforskningen. Climatic Research Unit ved University of East Anglia, Storbritannia med Hubert Lamb som direktør, var blitt etablert i 1971, men det var først med den internasjonale konferansen «Climate and History» i Norwich i juli 1979 at grunnen for alvor ble lagt for et organisert samarbeid mellom klimatologer og historikere. Konferanserapporten (Wigley et al. 1981) inneholdt blant mange bidrag to artikler som er blitt hjørnesteiner innenfor den historiske klimatologien. De er skrevet av Ingram et al. (1981a,b). I hovedsak er disse artiklene en gjennomgang av forskningsstatus innen klimaforskningen mot slutten av 1970-tallet, men et viktig utgangspunkt for begge er at historikerne har ignorert klimaets betydning for den historiske utviklingen (Ingram et al. 1981a:18) og har også vært lite villige til å delta med sin kompetanse, der det har vært aktuelt (Ingram et al. 1981b:182). Artikkelen til Ingram et al. (1981a) er en gjennomgang av innleggene på konferansen, men de tar også for seg alle aktuelle kildekategorier, både naturvitenskapelige og historiske. De understreker viktigheten av tverrfaglighet og vurderer brukbarheten av de ulike kildene. De er av den oppfatningen at en ikke skal overvurdere klimaets virkninger, og at undersøkelser med en profil der en legger vekt på lokale studier har bedre muligheter for å lykkes. Kortsiktige undersøkelser er å foretrekke framfor å undersøke langtidsvirkningene av klimaet. Artikkelen har ellers en mengde metodiske råd som skal sikre at klimadataene ikke blir overvurdert. De innfører den viktige distinksjonen mellom kortsiktige, mellomsiktige og langsiktige virkninger av klimaet på ulike samfunnsfelt (Ingram et al. 1981a:27-31), og de trekker også fram menneskenes evne til å tilpasse seg endringer i omgivelsene (Ingram et al. 1981a:3, 36-37), det de med et presist begrep kaller menneskenes evne til å tåle klimatisk stress (Ingram et al. 1981a:4). Artikkelen til Ingram, Underhill og Farmer konsentrerer seg om de ulike dokumentariske kildene som kan bidra med klimadata samt hvordan disse skal behandles for å kunne gi mest mulig kunnskap om klimavariasjoner og klimaets betydning for samfunn og mennesker. I begge artiklene legges det stor vekt på at de historiske dokumentardataene helst bør standardiseres, indekseres og tilrettelegges for statistisk behandling. Dokumentariske instrumentdata foretrekkes framfor kvalitative historiske data slik som 
ordinære opplysninger om generelle værforhold, avlingsstørrelser, uår, opplysninger om sult og fenologiske data. Det er ganske klart at denne opptattheten av at klimadataene helst bør bli gjenstand for statistisk behandling er en del av årsaken til at historikere var uvillige til å delta i samarbeid med klimatologer, meteorologer og representanter fra andre naturfag. Naturvitere er generelt mistroiske til de kvalitative aspektene ved historiske dokumentardata og ønsker å omgjøre dem til kvantitative størrelser slik de er vant til i sine egne fag.

På slutten av 1980-tallet ble Euro-Climhist dannet. Denne sammenslutningen sprang ut fra Universitetet i Bern, Sveits med historikeren Christian Pfister som drivkraft. Den hadde tilslutning fra institusjoner og enkeltpersoner fra en rekke europeiske land, deriblant fra Norge, og hovedsiktemålet var å samle inn ulike klimaopplysninger for å kunne konstruere værkart på europeisk skala i historiske perioder det fantes data fra. European Science Foundation (EPC), der de fleste europeiske land, inkludert Norge, er medlem, organiserte i 1989 et sjuårs prosjekt kalt «European Paleoclimate and Man since the last Glaciation» (EPC) som etablerte prosjekter, holdt konferanser og seminarer og publiserte rapporter. Rapportene inneholdt klimarelaterte artikler, der ulike kildekategorier ble behandlet og der konkrete undersøkelser ble omtalt. Det var flere norske bidrag. Noen rapporter tok for seg dokumentardata fra ulike perioder, bla. ble det gitt ut publikasjoner om 1300-tallet, perioden 1750-1850 (Wishman, Frenzel \& Weiss 1998) og Maunder Minimum-perioden 1675-1715 (Pedersen 1996). De fleste bidragene var skrevet av forskere med naturvitenskapelig bakgrunn, men også historikere deltok. Det er likevel grunn til å si at i den internasjonale forskningen på klimavirkninger var få historikere involvert. En av deltakerne i ødegårdsprosjektet, Helge Salvesen, har et bidrag i en av rapportene (Salvesen 1992:219-233). Salvesen drøfter klimavirkningene mer inngående enn tidligere og problematiserer forholdet mellom klimaendringer og endringer der sosiale og økonomiske årsaker har vært utslagsgivende. Grunnholdningen er imidlertid som før: Klima vil ofte være en medvirkende årsaksfaktor og kan fungere som en katalysator i en historisk prosess uten å være avgjørende for den løsningen en bestemt kultur vil velge som svar på en klimaendring (Salvesen 1992:232).

\section{Klimafaktoren i norske historieverk}

I perioden etter midten av 1970-tallet er det utgitt fem flerbindsverk der norsk historie har vært tema. Cappelen ga ut et verk i tolv bind i perioden 1976-1980, og Aschehoug publiserte et i samme format på 1990-tallet. Gyldendals satsing var et fembindsverk i perioden 1996-2000, der samtlige var skrevet av Karsten Alnæs. Samlaget ga ut sin versjon i 1999 i seks bind og Aschehoug et nytt verk i fire bind i 2011, kalt Norvegr-serien. Sentrale norske historikere i ulike generasjoner har vært engasjert som forfattere i disse publikasjonene. Jeg har gått gjennom de bindene som ligger innenfor den nå vanligste definisjonen av perioden «den lille istid», dvs. 1300-1850. Om disse verkene kan det kort slås fast at klimaytringer/ klimavirkninger har en helt minimal plass i framstillingene, og de blir heller ikke tillagt noen betydning for den historiske utviklingen.

Klimaet har også vært berørt i andre sammenhengende historiske framstillinger. Her kan trekkes fram landbrukshistorien nasjonalt og på Vestlandet. Kåre Lunden (2002) gir klimaet forholdsvis stor plass i sin landbrukshistorie, og trekker fram varmesum- og veksttidteorier samt har en gjennomgang av naturvitenskapelige metoder som kan gi informasjon om klimaendringer, men ender opp med å konstatere at klimaet ikke kan forklare reduksjonen i antall gårdsbruk i senmiddelalderen (Lunden 2002:35-40). Han nevner ofte klima og klimaskifter også for senere perioder (Lunden 2002:16, 32, 51, 151-159), men bare forbigående og uten videre drøfting. Han gjengir beretninger om klare sammenhenger mellom uår og klimaforverring fra alle de 500 årene han omtaler (Lunden 2002:277, 322) og klimaets negative betydning for fiskeriene (Lunden 2002:318, 324). Disse faktaopplysningene fører ikke til noen merknader om klimaet hadde noen grunnleggende betydning for utviklingen innen jordbruksnæringen og tilknyttete næringer. Ingvild Øye (2006) skriver om jordbruket på Vestlandet at kornavlingen i Hordaland var $40 \%$ høyere på 1300-tallet enn på 1600- og 1700-tallet og i Sogn kunne avlingen være opp mot $80 \%$ høyere (Øye 2006:106). Hun trekker ikke inn klimaet som mulig forklaringsfaktor, tvert imot beskriver hun klimaet som balansert og godt (Øye 2006:79).

Utenom de større norgeshistoriene og lignende oversiktspublikasjoner er klimaets betydning for historiske hendelser eller utviklingslinjer tatt opp i historisk forskning i ulike sammenhenger, men aldri som et sentralt og bærende tema, alltid som en biting der andre problemstillinger har vært det sentrale. Her kan nevnes forskere som har arbeidet med pestepidemier. Lars Walløe (1982) avviser at klimaet har hatt noen betydning på epidemiene med henvising til Lamb (1977), Ingram et al. (1978) og Hasund (1924). Ole Georg Moseng (2006) slår fast at lungepest først og fremst kan knyttes til områder med kaldt klima, til steder med vinterlige forhold (Moseng 2006:58, 65). Han kritiserer ødegårdsprosjektets avvising 
av klimaets betydning og anfører at ødeleggingen vanskelig kan forklares innenfor ødegårdsprosjektets teoretiske rammer (Moseng 2006:240). Moseng henviser til internasjonal litteratur som antyder at solflekkaktivitet og temperatursvingninger under den lille istiden er en mulig forklaringsfaktor til at pestepidemiene opphører på 1600og begynnelsen av 1700-tallet (Moseng 2006:514), men han forfølger ikke dette videre. Ole Jørgen Benedictow legger fram forklaringsmodeller til seinmiddelalderens økonomiske historie (Benedictow 1994:69-71), og da bruker han noe plass på klimateoriene; om klimaet skulle kunne gi noen bidrag til forståelse av Norges særutvikling i senmiddelalderen. Han viser til Bull og Holmsen og klimatologene Lamb og B. Ambrosiani og avviser helt at klimaet skal ha hatt noen betydning.

\section{Nyere norsk klimaforskning}

Audun Dybdahl som deltok i ødegårdsundersøkelsene, publiserte i 2010 (Dybdahl 2010) en artikkel som er den første siden 1920-tallet av en norsk historiker der klimaet er hovedsaken. I 2012 (Dybdahl 2012) fulgte han opp med en engelskspråklig artikkel der mange momenter var hentet fra den som kom to år tidligere. Han gir en definisjon av historisk klimatologi (Dybdahl 2010:184) som dekker de forskningsmessige målene som både klimatologer og historikere har. Han kommer også inn på hvorfor historikere ikke har brydd seg om de naturlige rammene for menneskenes leveforhold, og siterer den engelske antropologen Brian M. Fagan på at de ikke har fulgt med det som har skjedd innen palaeoklimatologien siden 1980-tallet (Dybdahl 2010:185). I forlengelsen av dette skriver Dybdahl at norske historikere i hovedsak har gitt sin tilslutning til det Hasund skrev om årsaken til nedgangen i senmiddelalderen, der klimaet ikke har en sentral plass. Han beskriver deretter engelske forhold og forskning, der han mener datagrunnlaget er bedre enn hva situasjonen er for Norge. Konklusjonen er vag; klimaet har spilt en varierende rolle, både tidsmessig og geografisk. (Dybdahl 2010:190). Han har en gjennomgang av diskusjonen blant norske historikere om forholdene når det gjelder agrar- og bosetningskriser i senmiddelalderen, og han leter etter spor i lovtekster og annet materiale etter ødegårder og landskyldreduksjon før Svartedauden. (Dybdahl 2010:190-207) Deretter relaterer han referanser til uår og dyrtid i sagaer og diplomer til dendrokronologiske data fra botanikeren Terje Thun, og han finner sammenheng mellom dendrodataene og historiske kilder (Dybdahl 2010:207-218). Han konkluderer med at det trolig er rett at de klimatiske langtidstrendene ikke kan ha hatt avgjørende innvirkning på bosetning og folketall (Dybdahl 2010:219, 2012:1165). Han tilføyer likevel at forskningen har undervurdert klimaet og mener at uår, matmangel, feilernæring og lignende kan skyldes ugunstige nedbørforhold og/eller lav temperatur. Dybdahl er av den oppfatningen at dersom en ønsker å få en sikrere erkjennelse omkring klimaets betydning for den demografiske utviklingen, må det satses sterkere på dendrokronologiske studier holdt opp mot relevant informasjon av naturhistorisk, arkeologisk og skriftlig art (Dybdahl 2010:221).

Dybdahl (2013, 2014a,b) har i flere senere artikler tatt opp klimarelaterte problemstillinger med ulike vinklinger. I en artikkel trekkes fram opplysninger om uår, omtalt i Kongespeilet, der klimavirkninger må tildeles betydelig vekt i forklaringen av bosetningsutviklingen i høy- og senmiddelalderen (Dybdahl 2013:100-101). I en annen, om uår i Norge på 1740-tallet, tas betydningen av klimaet opp (Dybdahl 2014a:9, 23). I begge er imidlertid konklusjonen at klimaet ikke kan tillegges avgjørende vekt, og at kildematerialet er for spinkelt til å kunne gå i detaljer og igjen trekkes verdien av dendrokronologien fram. I en omfattende artikkel går Dybdahl (2014b) inn på klima, uår, sykdom og demografiske kriser i Trøndelag på 1600- og 1700-tallet. Han legger fram en hypotese om at klimatiske sjokk har spilt en mer avgjørende rolle for de høye mortalitetstallene enn det som synes å ha vært oppfatningen til mange norske historikere (Dybdahl 2014b:244). Han trekker fram ulike klimakilder, både skriftlige og naturvitenskapelige, går kort gjennom hva enkelte historikere har ment om klimafaktoren siden ødegårdsundersøkelsene og slår fast at klimaet ikke tillegges vekt (Dybdahl 2014b:247). Det viktigste resultatet som kommer fram, er at det kan påvises en klar sammenheng mellom uårssekvenser og overdødelighet. For enkelte av disse uårssekvensene har klimatiske forhold spilt en avgjørende rolle for den høye dødeligheten, men først og fremst er nok hungersnød en utløser og katalysator for smittsomme sykdommer (Dybdahl 2014:274).

Dybdahl står for den grundigste og mest innsiktsfulle gjennomgangen av klimaets betydning for den historiske utviklingen og er den som har best kunnskap til historisk klimatologi som forskningsfelt, og da særlig om det som har foregått internasjonalt. Men som de fleste før seg har han mest tro på at det er de naturvitenskapelige metodene som gir de største mulighetene til å kaste lys over klimaets betydning for den historiske utviklingen, og at de skriftlige kildene ikke strekker til.

Det har vært enkelte norske forskere fra ulike naturfag som har arbeidet med historiske dokumentardata fra skriftlige kilder. Her kan nevnes Elisabeth Kastellet(1996), Elin Lundstad (2004), Erik H. Wishman (2007) og Øyvind Nordli (2008). De har stort sett hentet sitt kildemateriale 
fra gårdsdagbøker fra 1700- og 1800-tallet, en kildekategori som ikke har vært brukt av historikere innen klimaforskningen. Disse forskerne har i utgangspunktet ikke vært interessert i å bruke dette kildematerialet til å lage beretninger om hvordan klimaet har påvirket menneskers liv i historien. De enkelte klimaopplysningene blir indeksert, dette er en metode for å sette kvalitative, historiske data over til en kvantitativ form, dvs. gi de ulike klimaytringene tallverdier for å kunne gjennomføre statistiske beregninger. Hensikten har vært å rekonstruere det historiske klimaet på ulike steder til ulike tider, og det endelige målet er å få en tilnærmet fullstendig oversikt over værbevegelsene så langt tilbake i tid som mulig. Dette skal bidra til å bedre grunnlaget for å kunne gi mer korrekte værvarslinger i vår egen tid. Et poeng har også vært å få mer kunnskap om hvordan klimaet utvikler seg over tid, og hvilke utviklingstrender som ligger bak naturkatastrofer der klimaendringer har spilt inn.

\section{Historiske kilder i klimaforskningen}

Et argument som går på både kvaliteten til det skriftlige kildematerialet og på teknisk-metodiske aspekter, trekkes stadig fram. De fleste som har vært innom temaet skriver at det ikke finnes tilstrekkelig med historiske kilder om klima og klimavirkninger til å kunne gi en fyllestgjørende og dekkende behandling av saksområdet. Kildene er også vanskelige å finne, og det er komplisert å skille dem fra andre kildetyper som kan ha bidratt til at en spesiell historisk utvikling eller hendelsesrekke har inntruffet.

Når det gjelder kilder om klima så er det, som på de fleste emneområder i middelalderen, små og sporadiske forekomster. Men de finnes, og dersom en samler alle de opplysningene som er registrert av deltakerne i ødegårdsprosjektet, av historikere som Bull, Hasund og Lunden samt enkeltnoteringer fra andre historikere så blir det et grunnlag for et videre arbeid. Fra de 300 årene etter reformasjonen er påstanden om manglende kildetilfang grunnløs. Det finnes i realiteten mengder av kildemateriale med til dels svært nøyaktige opplysninger om klimaytringer, klimaendringer og klimavirkninger. Kildene kan i hovedsak deles inn i tre kategorier: 1. Kilder der klima er viktigste element, 2. Kilder med konkrete klimadata, men der disse har underordnet betydning og 3. Kilder som gir indirekte klimainformasjon (Pedersen 1994:14-16). Under punkt 1 kan nevnes topografiske beskrivelser, dagbøker, avisnotiser, instrumentmålinger. Under punkt 2 kan trekkes fram dagbøker der klimaet ikke er viktigste bestanddel, biografier, tingbøker, kirkebøker, særskilte opplysninger i jordbrukstellinger, offentlig og privat korrespondanse, merknader i matrikler, skattelister, supplikker, skifter, reisebeskrivelser, rapporter fra underordnet offentlig instans til sentrale myndigheter, sagalitteratur og under punkt 3 tallmessige oppstillinger fra folke- og jordbrukstellinger, skattelister, regnskaper og tallmessige oppgaver om endringer innen næringsrelatert produksjon og handel. Enkelte kilder kan være rene gullgruver slik som de beste dagbøkene (for eksempel Augustinssøn 1894, Grude 1914), biografiene (Malthus 1968) eller de topografiske journalene (Strøm 1796, 1798), mens andre inneholder færre opplysninger som er mer arbeidskrevende å få fram. I sum må en likevel kunne si at det finnes tilstrekkelig med kildemateriale til å få substans i klimahistoriske undersøkelser, i det minste gjelder det punktstudier både tidsmessig og geografisk.

Siden norske historikere allerede i utgangspunktet har avvist at klimaet skulle ha noen særskilt betydning $\mathrm{i}$ historisk sammenheng, har en ikke brydd seg med å utvikle teoretiske og metodiske grep for å nyttiggjøre seg den informasjonen og det kildetilfanget som de fleste innser tross alt finnes. Det blir stadig understrekt at klimaet og klimavariasjonene inngår i de naturgitte rammebetingelsene som nordmenn i tidligere tider måtte inngå i. Selv om en har vært klar over at klimaendringer inntraff, så har disse ikke endret historiens løp i vesentlig grad, og en har ikke vært innstilt på å fortelle de historiene om dette temaet som tross alt hadde latt seg fortelle. Kildene beskriver hendelser som etterlater et klart inntrykk av hvor traumatisk det må ha vært å oppleve at avlingen sviktet tre år på rad, at titalls fiskere mange ganger forsvant i bølgene, at småbrukene som familier levde på i løpet av kort tid ikke ble drivverdige lenger og måtte fraflyttes, og at det ofte var uår og sult. En har stilltiende avskrevet de langsiktige virkningene av klimaendringene som uinteressante siden det har vært lite å gjøre med dem og dessuten har folk knapt merket at de har skjedd. En har heller ikke brydd seg nevneverdig om katastrofene, de kortsiktige hendelsene, som kildene er fulle av. Det er noe som alltid inntreffer, og det er lite å lære av dem, siden ingen samfunn kan ha en beredskap som tar høyde for dem. Men som Ingram et al. (1981a) peker på: De mellomsiktige hendelsene er ideelle for historiske granskinger. Her har folk i de ulike samtidene vært klar over de problemene klimaet og endringene medførte, og da er det mulig å analysere hva folk gjorde for å hindre eller minimalisere virkningene. Hvis ingenting ble gjort, er dette også interessant siden det kan fortelle mye om innretningen på samfunnene og samfunnsstyringen. Disse mellomsiktige hendelsene har heller ikke interessert norske historikere.

Været har alltid opptatt nordmenn, det kan en som nevnt slå fast på grunnlag av de utallige værmerkene som går langt bakover i tid og som har fungert som veivisere 
og varsellamper. Årsaken til at denne interessen ikke er enda mer synlig i kildetilfanget, er at den har vært skjevt fordelt. Adelen, embetsmennene, de geistlige, storbøndene og byborgerne var minst interessert siden utslagene av dårlig værforhold betydde lite for dem. Siden det var disse gruppene som sto bak det skriftlige materialet som har overlevd til våre dager, så er klimavirkningene blitt sterkt underrapportert og dermed også undervurdert. Klimaet traff for det meste småbrukerne, fiskerne, husmennene og tjenestefolket. Disse har bare unntaksvis kommet til orde i kildene og er dermed blitt nesten usynlige i de historiske framstillingene. Ingram et al. understreker at en viktig forskningsoppgave må være å undersøke hvordan mennesker tidligere reagerte på klimaendringer, hvordan de tålte klimatisk stress, og dette mener de kan ha overføringsverdi til dagens samfunn. De mellomsiktige klimahendelsene er godt tilpasset en slik forskningsstrategi. I tillegg til en revisjon av tidligere oppfatninger når det gjelder verdien av å arbeide med klimaspørsmål, vil det imidlertid kreve samarbeid med andre fagområder slik som psykologi, folkeminnevitenskap, de samfunnsfagene som driver med risikoanalyse og samfunnsberedskap, for å nevne noen.

\section{Representativitet}

Hensikten med denne gjennomgangen av norsk historieforskning og -skriving har vært å få en så full oversikt som mulig både over hvilken betydning norske historikere har tillagt klimaendringene og også i hvilken grad historiske, skriftlige kilder har vært brukt i historiske framstillinger. Det har vært et klart mål at alt som er utgitt av forskning om temaet skal være inkludert. Det samme gjelder populærvitenskapelige publikasjoner som har vært forskningsbasert. Oversikten viser at ingen artikler eller monografier har hatt klima eller klimaendringer som overordnet innfallsvinkel til forståelsen av en historisk periode eller et historisk problem av noe omfang, bortsett fra helt opplagte enkelthendelser.

Det er en relevant innvending å trekke fram at det er først de siste tre tiårene at klimaet er blitt oppfattet som truende på en helt annen måte enn tidligere, særlig i en global, men etter hvert også i en nasjonal, sammenheng. Det er derfor vanskelig å bebreide forskningen før denne tiden at den la lite vekt på klimaelementet. En må da kunne peke på at selv i denne siste perioden er klimautfordringene i liten grad blitt satt på dagsorden forskningsmessig av norske historikere. Og selv om bevisstheten om klimaendringenes betydning var lavere fram til siste halvpart av 1900-tallet, er det likevel underlig at et naturfenomen med så stor innvirkning på menneskers daglige liv, har vekket så liten interesse. De faginstitusjonelle forholdene innen historieforskningen har gjort det vanskelig å finne en plass til denne forklaringsmåten.

Et tilleggsmoment er at den vitenskapelige gehalten i mye av forskningen ikke er av høy kvalitet og har til dels preg av synsing. Den har derfor vært lett å avfeie.

En må slå fast at norske historikere ikke har hatt tillit til sitt eget primærkildemateriale. Med en slik påstand har det vært nødvendig å gå så grundig til verks og gi en tilnærmet full dekning av historieforskningen og -skrivingen på klimafeltet.

\section{Klimarelaterte innfallsvinkler i forskningen}

I norsk historieforskning og -skriving er det altså mangel på en overordnet, prinsipiell drøfting av klimavirkningenes plass blant de leddene i en årsakskjede som fører til historisk utvikling og da særlig endring. I utenlandsk forskningslitteratur er dette spørsmålet i flere faser blitt grundig behandlet. Alle er for så vidt enige i at historikere, på et generelt nivå, har vært lite interessert i å trekke inn klimaet som en årsaksfaktor, men begrunnelsen, mangfoldet av og dybden i argumentasjonen, har vært langt større i utenlandsk forskning. En del av slutningene til Ingram et al. (1981a:4) er nevnt ovenfor; at det er svært vanskelig å få fatt i klimaets betydning for den historiske utviklingen og at klimaet i lange perioder har betydd lite. De legger sterk vekt på hvordan samfunn har tilpasset seg klimatisk stress (Ingram et al. 1981a:4, 36, 37), men de føyer til et moment som ikke finnes i den norske diskusjonen; at et motiv for klimaforskning må være empati for de før oss som slet med klimavirkningene og også hensynet til de kommende generasjonene (Ingram et al. 1981a:5). En må huske på at dette ble skrevet et tiår før problemene med nåtidens klimaendringer ble allment erkjent. Ingram et al. (1981a:18) slo fast at historikere har ignorert klimavariabelen og begrunnelsen har vært: a) klimaet har vært stabilt, b) klimavariasjonene har vært for små, c) det har manglet data på feltet og d) det har vært liten kunnskap om forholdet mellom klima og historisk utvikling.

Som nevnt økte interessen for og omfanget av klimahistorisk forskning internasjonalt sterkt fra rundt 1980 og framover. Flere av de som hadde vært engasjert i denne forskningen, både historikere og naturvitere, skrev en oppsummering i Climatic Change i 2005 (Brázdil et al. 2005). Det er en svært nyttig artikkel som definerer historisk klimatologi og hvordan fagfeltet har utviklet seg (Brázdil et al. 2005:365). I artikkelen tar de for øvrig for seg hovedproblemstillingene i forskningen, klimahistoriens utvikling, forskjellige datatyper, alle mulige kildetyper fra en rekke fagområder og hvordan indeksering av 
dataene foregår med kalibrering, verifikasjon og rekonstruksjon. Videre går de inn på ulike klimatiske inndelinger av de siste tusen år, bl.a. hvordan enkeltforskere deler inn «den lille istiden», og de ser på sammenhengen mellom klimaytringer og den virkningen de har hatt på samfunnet, på dyrking og avkastning, på sult og død og på sosiale opprør ulike steder i Europa. De konstaterer at den historiske klimatologien har hatt stor framgang, og at datatilfanget er blitt stadig større, og likevel har historikerne forsvunnet fra emnet (Brázdil et al. 2005:369, 370). Deres viktigste begrunnelse er at historikere har vært redde for klimadeterminismen og hangen til å forklare alle personlige og samfunnsmessige ulykker med klima.

Den svenske historikeren Fredrik C. Ljungqvist har gitt den mest oppdaterte beskrivelsen av klimautviklingen siden siste istid, inkludert en bred omtale av historisk tid. Han definerer den lille istid til perioden 1300-1900 (Ljungqvist 2009:163) og i sin grundige gjennomgang finner han årsaken til klimavariasjonene i solaktiviteten, et lavt antall solflekker, variasjoner i kosmisk stråling samt endringer i havsirkulasjonen. Han slår fast at i NordAtlanteren var det 2-3 grader kaldere i denne perioden enn i dag (Ljungqvist 2009:165). De kaldeste periodene var på 1300-tallet, fra slutten av 1500-tallet til begynnelsen av 1700-tallet og 1800-tallet (Ljungqvist 2009:169). Det kalde klimaet hadde begrenset virkning kulturelt og for de herskende klassene, det var bøndene som ble rammet (Ljungqvist 2009:200). Han mener at endringene i nedbørsmengde har vært mer utslagsgivende enn endringer i temperaturen (Ljungqvist 2009:10). Frekvensen av misvekstår økte fra 1:200 til 1:3 i midtre del av den lille istid (Ljungqvist 2009:220). 1690-årene (Maunder Minimum) og årene 1790-1802 (Dalton Minimum) var de kaldeste periodene de siste 1000 år (Ljungqvist 2009:231, 243), i 1696 og 1697 døde ca. en tredjedel av Finlands befolkning av sult og sykdommer, i stor grad klimarelatert. Ljungqvist mener at fra begynnelsen av 1800-tallet hadde dyrkingssystemene utviklet seg slik at samfunnene begynte å bli immune mot klimautslag. Han slår fast, som en rekke andre gjør, at historikerne ikke har interessert seg for klimavariasjonene i fortiden. Årsakene til dette har vært at historikerne har ment at klimaendringene har vært små, at klima ikke har inngått i historikernes forklaringsmodeller, at historikerne har hatt en tendens til å tone ned elementer som ligger utenfor menneskenes påvirkingsmuligheter og at de har manglet kunnskap om klimavariasjoner (Ljungqvist 2009:12, 13). Men selv om han trekker fram klimaet når han beskriver den historiske utviklingen så skriver han at klima bare er en årsak og ikke alltid den viktigste, til historisk endring (Ljungqvist 2009:14). Dette er nok korrekt dersom en i begrepet historisk endring legger helt fundamentale nye historiske utviklinger til grunn. Det kan diskuteres hvor mange endringsprosesser av en slik art det har vært de siste 1000 årene, og dessuten er det andre problemstillinger som har vært viktige og samfunn og mennesker som kan være vel verd å undersøke nærmere.

Denne gjennomgangen viser at norske historikere, med svært få unntak, har vært av den oppfatningen at klimaet har hatt ingen eller en helt marginal betydning for den historiske utviklingen i Norge de siste 700 årene. Enkelte, som Edvard Bull (1913, 1915-16, 1925, 1931), har tillagt klimaet en viss vekt, riktignok uten å underkaste temaet en grundig undersøkelse. De fleste har avvist at klimaet har hatt relevans, eller de har ignorert saksområdet helt. Noen har gått grundigere til verks, her kan nevnes Jørn Sandnes, Helge Salvesen (1975, 1979, 1992), Frode Fyllingsnes (1990) og Audun Dybdahl (1979, 2010, 2012, 2013, 2014a,b), men også disse ender opp med å avvise klimaets betydning som en fruktbar inngang til en utvidet forståelse av norsk historisk utvikling. Ingen har formulert helt klart hvorfor klimaendringer og klimavirkninger ikke skulle ha noen innvirkning på den generelle samfunnsmessige utviklingen eller for livsbetingelsene til nordmenn før oss. Det er likevel mulig å trekke ut noen argumenter fra de utsagnene norske historikere er kommet med om denne problemstillingen.

Det viktigste er av overordnet, historiefilosofisk art slik det er blitt dokumentert i framstillingen. En vil unngå å bruke beviser på utvikling og endring som ikke er forankret i historiefagets egenart. Økonomiske, sosiale, demografiske og politiske elementer skal forklares med bakgrunn i økonomiske, sosiale, demografiske og politiske kilder og argumentasjonsrekker. Det blir oppfattet som utilfredsstillende og fagfremmed å bruke naturlige hendelser eller naturspesifikke endringer i en historiefaglig diskurs. Når den naturbestemte hendelsen er av et slikt omfang at den er umulig å ignorere, så blir den nevnt, men endringene i de naturgitte rammebetingelsene blir fort akseptert og utgjør et nytt ståsted for analyse som vanligvis omfatter de økonomiske etc. virkningene av for eksempel en naturkatastrofe. I en slik kontekst må en se noe av motstanden mot å gi klimaytringer en mer betydningsfull plass i den historiske framstillingen.

\section{Norske historikere og tverrfagligheten}

Som det går fram av denne gjennomgangen, så er ikke historikere flinke når det gjelder samarbeid med andre fag. Mange av de historikerne som har vært referert i teksten, kan i utgangspunktet ha vært interessert i å arbeide med klimaets betydning, men har gitt opp pgra. det de mener er den dårlige kildesituasjonen. Da har svært mange vendt 
seg til ulike naturvitenskapelige fag og metoder, vanligvis til pollenanalyse og dendrokronologi, og etterspurt løsninger herfra. Da har det vært meningen at naturfagene skulle komme opp med datamateriale og analyser som kunne besvare de spørsmålene historikerne ikke har kunnet gi svar på, basert på egne problemstillinger og kilder. Disse forventningene til naturfagene er aldri blitt innfridd fordi de er umulige å innfri. De misforstår fundamentalt naturfagenes rolle og posisjon innen klimaforskningen. Disse fagene har egne mål med sin forskning som de forfølger, og de er i utgangspunktet ikke identiske med historikernes mål. Historikere kan få ta del i naturfagenes kunnskap, men da må de inngå i forpliktende, gjensidige samarbeidsrutiner med naturviterne slik at det blir et utbytte av samarbeidet for begge parter. Dette er vanskelig for humanistiske fag, og har da også ført til utstrakt redsel for klimadeterminisme hos historikere som har prøvd å etablere samarbeidsrutiner. Naturviternes ønsker om metodeutvikling, basert på kvantitative verdier, kolliderer i utgangspunkt med historikernes vektlegging av de kvalitative egenskapene til dataene, der primærhensikten er forståelsen av en historisk situasjon, ikke bare forklaringen av den ${ }^{1}$. Imidlertid, når en er klar over denne viktige distinksjonen, så er det mulig å etablere samarbeidsrutiner, og det har også vært gjort (Pedersen \& Kalela-Brundin 1998). Innen arkeologien, et annet humanistisk fag, har en klart å lage samarbeidsprosjekter med ulike naturvitenskaper, der det har blitt et forskningsmessig utbytte for begge partene.

Det har vært omfattende forskning på klimaspørsmålet i ulike utenlandske miljøer, særlig har universiteter og forskningsinstitusjoner i USA, Storbritannia, Tyskland, Sveits, Sverige og Frankrike vært framtredende. I enkelte, riktignok kortvarige, faser har norske historikere vært oppdatert på det som skjedde i utlandet, på 1910- og 1920-tallet samt til en viss grad innenfor rammen av ødegårdsprosjektet. Det normale har imidlertid vært, noe tekst og litteraturhenvisinger signaliserer, at norske historikere i liten grad har vært internasjonalt orientert. Ingen legger skjul på at det har vært problemer i samarbeidsrelasjonene mellom naturvitere og humanister. Det er formen i samarbeidsrutinene og frykten, særlig hos humanistene, for å bli hjelpevitenskaper til naturfagene som har skapt problemene. Dette er en konflikt som alltid vil være der, og som det kreves aktivt samarbeid for å motvirke de negative følgene av.

\section{Har historiefaget neglisjert et samfunnsoppdrag?}

Innledningsvis ble den faretruende situasjonen i forbindelse med den globale oppvarmingen trukket fram.
Endringene i klimaet kan få svært alvorlige følger. En står riktignok overfor en noe annerledes problemstilling enn tidligere. Det mest aktuelle nå er en global oppvarming, mens det i historiske tider har vært perioder med både klimaforverring og perioder med bedre klima. Nå som i tidligere tider er det de mest ressurssvake som sannsynligvis vil lide mest, ikke de fattige og eiendomsløse i Norge, men mennesker i de fattige landene i den tredje verden. Et flertall av vitenskapsfagene, særlig innenfor natur- og samfunnsvitenskapene, men også i humanistiske fag, ${ }^{2}$ har konsentrert deler av sin innsats og sine ressurser på å finne fram til ny kunnskap om bakgrunnen for klimaendringene og den virkningen de vil ha lokalt og globalt. I denne sammenhengen er norsk historieforskning helt fraværende, det er ingen forsøk på å få fram i lyset hvordan en tidligere har forholdt seg til klimaendringer i Norge. I andre sammenhenger har en kunnet trekke fram historisk kunnskap i et forsøk på å belyse aktuelle samfunnsmessige problemer. Det er ikke umulig at erfaringer fra hvordan en løste problemer knyttet til klima i århundrene før oss, eller muligens like aktuelt, unnlot å løse disse problemene, kan gi innsikt i aktuelle problemstillinger.

Historiefaget i Norge har hatt flere muligheter til å arbeide med klimaspørsmål, og det burde være naturlig at dette ble et viktig forskningstema. Men mens andre fag har grepet denne muligheten, har historiefaget unnlatt å gjøre det.

\section{Summary}

The point of departure of this article is that the climatic situation confronting the world is the most important issue concerning life on earth in the future. Why is it so, then, that Norwegian historians, seemingly to a large degree, have avoided considering the consequence of climate for the development of Norwegian history. Even after climate change became an important political topic, Norwegian historians, contrary to researchers from almost all other subjects, have avoided to engage in this theme.

A thorough survey is made on how Norwegian historians have treated the significance of climate on the historic development in the last 100 years of historical research. Except for a few short periods, in the middle of the 1920's and in the 1970's the interest has been almost non-existing. To an almost unanimous degree Norwegian historians agree that all historical problems, whether they are political, social, economic or demographic, must be solved through the use of political, social, economic or demographic sources and arguments. Natural occurrences, mostly climate related, but also f.ex. volcanic eruptions and landslides, are mentioned within this framework. The result is that only incidents, which are caused by human behavior or human actions and have consequence for humans, are the object of historical research. Climatic disasters may be mentioned but 
both the short term and the long term effects of an disaster are neglected and focus will be on a description of the new situation in the society as if nothing spectacular just happened. There are of course reasons for this; on the one hand the fear of climate determinism among historians and on the other the fact that natural disasters have more effect on the life of the poor and propertyless who are invisible in the historical sources. In the article it is, however, documented that relevant sources exist but that they may be difficult to collect since a thorough investigation is demanded.

Climate research on the international level is described which is quite different from the situation In Norway. Several projects such as the "Euro-Climhist" and the "European Palaeoclimate and Man since the last Glaciation" and institutions like "European Science Foundation" and "Climate Research Unit" at the University of East Anglia are highlighted. A continuous interest in the impact of climate on the historical development from an early stage and with stronger emphasis from the 1940's until today is described. The publications which have been the result of these efforts are discussed and a theoretical basis is drawn from which relevant issues can be made related to the historical source material.

There is a focus on the need for interdisciplinary cooperation to obtain results in the field of climate research in the Humanities. Such cooperation is necessary, but it is emphasized that it can also create problems and that a subject as history easily can become a weak part. The only way to overcome such difficulties is to engage in practical cooperation, and it is a fact that Norwegian historians rarely cooperate with anyone, even with peers. This unlike the international situation where a substantial interdisciplinary cooperation has led to important results.

\section{Referanser}

Arbo Høeg, O. 1944. Dendrokronologi. Viking, bind VIII, 231-282.

Augustinssøn, M. 1894. Melchior Augustinssøns Annaler (i utdrag av L. Daae). Personalhistorisk Tidsskrift 1894, Bind 3.

Benedictow, O.J. 1994. Forklaringsmodeller i seinmiddelalderens økonomiske historie. I Langholm, S. (red.). Den kritiske analyse. Festskrift til Ottar Dahl på 70-årsdagen 05.01.94, 69-71. Universitetsforlaget.

Brázdil, R, Pfister, C., Wanner, H., von Storch, H \& Lutherbacher, J. 2005. Historical climatology in Europe the state of the art. Climatic Change 70, 363-430.

Brückner, E. 1890. Klimaschwankungen seit 1700. Geographische Abhandlungen, B. 4, Hefte 2. Wien.

Bull. E. 1913. Klima og historie. Samtiden, 200-208.

Bull, E. 1915-1916. Islands klima i oldtiden. Geografisk Tidsskrift, Bind 23, 1-5. København.

Bull, E. 1925. Klimaskifte og nedgang i Noreg i seinmillomalderen. Syn og segn, 12-19.

Bull, E. 1931. Det norske folks liv og historie gjennem tidene. Fra omkring 1000 til 1280. Aschehoug.

Christensen, R.T. 1925. Ein gamal norsk utpost. Dei nyaste utgravingane på Grønland. Syn og segn, 252-303.

Dybdahl. A. 1979. Stjørdalen gjennom bølgedalen. Universitetsforlaget.
Dybdahl, A. 2010. Klima og demografiske kriser i Norge i middelalderen og tidlig nytid. Historisk tidsskrift, 2, 183-222.

Dybdahl, A. 2012. Climate and demographic crises in Norway in medieval and early modern times. The Holocene, $1159-1167$.

Dybdahl, A. 2013. Om uår og ødegårder I Kongespeilet og andre skriftlige kilder fra høymiddelalderen. Collegium Medievale vol. 26, 89-106.

Dybdal, A. 2014a. Sult eller sykdom? Hva var årsaken til den demografiske krisen i Norge først på 1740-tallet? Michael 11, 9-27.

Dybdahl, A. 2014b. Klimatiske sjokk, uår, sykdom og demografiske kriser i Trøndelag på 1600- og 1700-tallet. Historisk tidsskrift, bind 93, 243-275.

Daae, L. 1984. Uaar og Hungersnød i Norge 1740-1743. Norske historikere i utvalg VIII. Opptrykk av artikkel første gang utgitt i 1868 av Videnskabsselskabet Kristiania. Forhandlinger.

Fyllingsnes, F. 1990. Undergongen til dei norrøne bygdene på Grønland i seinmellomalderen. Eit forskningshistorisk oversyn. Middelalderforum, Skrifter 2. Oslo.

Fægri, K. 1945. Pollenanalysen. En oversikt. Viking, bind IX, 45-119.

Grude, M.A. 1914. Jaderen 1814-1914. Bidrag til den økonomiske og kommunale Udviklingshistorie. 1ste Del. Almene Fæellesanliggender. Ingvald Dahles Forlag, Sandnes.

Hasund, S. 1924. Var det eit klimat-omskifte? Syn og segn, 289-299.

Hasund, S. 1925a. Var det eit klimatumskifte? Syn og segn, 8-11.

Hasund, S. 1925b. Grønland og klimat-teorien. Syn og segn, 69-73.

Hasund, S. 1934. Det norske folks liv og historie gjennem tidene. Tidsrummet 1280 til omkring 1500. Aschehoug.

Holmsen, A. 1948. Norges historie, bind 1. Fra de eldste tider til 1660. Gyldendal.

Holmsen, A. \& Johannessen, K. 1971. Det norske ødegårdsprosjektet. Heimen, XI, 223-233.

Holmsen, A. 1975. Nyrydning og ødegårder i Norge før Svartedauden. Heimen, XVI, 481-490.

Homme, T. 1925. Noko om Noregs nedgang i slutten av millumalderen. Syn og segn, 114-118.

Hulme, M. 2009. Why we disagree about climate change. Cambridge University Press.

Huntington, E. 1913. Changes of Climate and History. American Historical Review, Vol. 18, No. 2, 213-232.

Haarstad, K. 1980. Sult, sykdom, død. Et teoretisk problem belyst med empirisk material. Historisk tidsskrift, bind 59, $1-25$.

Ingram, M.J, Underhill, D.J. \& Wigley, T.M.L. 1978. Historical climatology. Nature 276, 329-334.

Ingram, M.J., Farmer, G. \& Wigley, T.M.L. 1981a. Past climates and their impact on Man: a review. I Wigley, T.M.L., Ingram, M.J. \& Farmer, G. 1981 (red.). Studies in past climates and their impact on Man, 3-50. Cambridge University Press.

Ingram, M.J., Underhill, D.J. \& Farmer, G. 1981b. The use of documentary sources for the study of past climates. I Wigley, T.M.L., Ingram, M.J. \& Farmer, G. 1981 (red.). Studies in past climates and their impact on Man, 180-213. Cambridge University Press. 
Johnsen, O.A. 1924. Norgesveldets undergang. Et utsyn og et opgjør. Nedgangstiden. Aschehoug.

Kastellet, E. 1996. Historiske klimadata som kilde til rekonstruksjon av klima på Jæren i perioden 1821-1850. Upublisert hovedoppgave ved Geografisk Institutt, Universitetet i Bergen.

Koht, H. 1933. Edv. Bull. Scandia, vol. VI, 142-152.

Ladurie, E. Le Roy 1967. Histoire du climat depuis l'an mil. Flammarion. Paris.

Ladurie, E. Le Roy 1971. Times of Feast, Times of Famine. A History of Climate since the Year 1000. Doubleday, New York

Lamb, H.H. 1972. Climate: Present, Past and Future, Vol. 1. Fundamentals and Climate Now. Methuen.

Lamb, H.H. 1977. Climate: Present, Past and Future, Vol. 2. Climatic History and the Future. Methuen.

Ljungquist, F. 2009. Global nedkylning. Norstedts Förlag.

Lunden, K. 2002. Norges landbrukshistorie II, 1350-1814. Frå Svartedauden til 17. mai. Det Norske Samlaget.

Lundstad, E. 2004. Rekonstruksjon av klimaet på Hamar 1749-1835 basert på gårdsdagbøker. Upublisert hovedoppgave ved Institutt for geografi, Universitetet i Bergen.

Malthus, T.R. 1968. Reisedagbok for Norge 1799. J.W. Cappelens Forlag AS, Oslo.

Mangerud, J. 1992a. Naturlige klimavariasjoner (1) - Istider og mellomistider. Naturen 2, 70-76.

Mangerud, J. 1992b. Naturlige klimavariasjoner (2) - Årsaker til istider og mellomistider. Naturen 3, 115-123.

Mangerud, J. 1992c. Naturlige klimavariasjoner. Dynamisk forståelse av klimaendringene. Naturen 4, 157-164.

Matthes, F.E. 1939. Report of the committee of glaciers. Transactions of the American Geophysical Union, 518-523.

Milankovic, M. 1920. Théorie mathématique des phénomènes thermiques produits par la radiation solaire. GauthierVillars, Paris.

Moseng, O.G. 2006. Den flyktige pesten. Vilkårene for epidemier i Norge i seinmiddelalder og tidlig nytid. Doktorgradsavhandling, Det humanistiske fakultet, Universitetet i Oslo.

Nansen, F. 1925. Klimat-vekslinger i Nordens historie. Avhandlinger utgitt av Det Norske Videnskaps-Akademi i Oslo, 1. Matem.-Naturvid. Klasse, No. 3.

Nansen, F. 1926. Klima-vekslinger i historisk og postglasial tid. Det Norske Videnskaps-Akademi i Oslo, 1. Matem.Naturvid. Klasse 1926, No. 3.

Nordli Ø. 2008. Norwegian farmers' diaries used for quality control and calibration of early instrumental observations and for temperature reconstructions. Dr.philos.avhandling, Universitetet i Bergen.

Nordmann, V. 1925. Klimatforandringer i de nordlige Polarlande, del 1. Naturens verden, 97-116.

Nørlund, P. 1924. Buried Norsemen at Herjolfsnes. An Archaeological and Historical Study. Meddelelser om Grønland, vol. 67. København.

Pedersen, E.S. 1994. Klimaets betydning i norsk historie. Frá haug ok heiðni 2, 13-17.

Pedersen, E.S. (red.). 1996. North European climate data in the latter part of the Maunder Minimum period A.D. 1675-1715. AmS-Varia 25, Stavanger.
Pedersen, E.S. \& Kalela-Brundin, M. 1998. Utvalgte år $i$ en årringskurve frå Suldal, Nord-Rogaland, korrelert med historiske klimadata. AmS-Varia 32, 41-51.

Pettersson, O. 1913. Klimatförändringar $i$ historisk och förhistorisk tid. Uppsala.

Røstad, A. 1924a. Verumskifte fyre nedgangstida i Noreg. Syn og segn, 209-214.

Røstad, A. 1924b. Var det auking i luftstrøyminga? Syn og segn, 401-415.

Salvesen, H. 1975. Naturgeografi og arkeologi som kilde for agrarhistorien. En introduksjon til en tverrfaglig undersøkelse av gården Hoset. Heimen, 491-506.

Salvesen, H. 1979. Jord i Jemtland. Bosetningshistoriske og økonomiske studier i grenseland ca. 1200-1650. Östersund.

Salvesen, H. 1992. The climate as a factor of historical causation. I Frenzel, B., Pfister, C. \& Gläser, B. (red.). European climate reconstructed from documentary data: methods and results, 219-233. Paläoklimaforschung, Vol. 7. Gustav Fischer Verlag.

Sandnes, J. 1971. Ødetid og gjenreising. Trøndsk busetningshistorie ca. 1200-1600. Universitetsforlaget.

Sandnes, J. \& Salvesen, H. 1978. Ødegårdstid i Norge. Det nordiske ødegårdsprosjektets norske undersøkelser. Universitetsforlaget.

Schreiner, J. 1948. Pest og prisfall i senmiddelalderen. Et problem i norsk historie. Avh. utgitt av Det norske videnskaps-akademi i Oslo, II. hist.-filos. klasse, no. 1. Jacob Dybwad.

Schreiner, J. 1946-48. Bemerkninger til professor Sverre Steens anmeldelse. Historisk Tidsskrift, bind 34, 667-674.

Steen, S. 1930. Det norske folks liv og historie gjennem tidene. Tidsrummet 1640 til omkring 1720. Aschehoug.

Steen, S. 1932. Det norske folks liv og historie gjennem tidene. Tidsrummet 1720 til omkring 1770. Aschehoug.

Steen, S. 1933. Det norske folks liv og historie gjennem tidene. Tidsrummet 1770 til omkring 1814. Aschehoug.

Steen, S. 1935. Det norske folks liv og historie gjennem tidene. Tidsrummet fra omkring 1500 til omkring 1640. Aschehoug.

Steen 1946-48. Anmeldelse av Johan Schreiner, Pest og prisfall i senmiddelalderen. Avhandlinger fra Videnskapsakademiet i Oslo, Historisk Tidsskrift, bind 34, 654-667.

Strøm, H. 1796. Meteorologiske Iagttagelser på Eger for Aaret 1794. Topographisk Journal for Norge, Hefte 15, 101-109.

Strøm, H. 1798. Udtog af 10 Aars meteorologiske Iagttagelser paa Eger. DKNVS, bind 1, Hefte II. Post og Storch Forlag, Kjøbenhavn.

Sørensen, M. \& Fugl Eskjær M. 2014. Klima og mennesker. Humanistiske perspektiver på klimaforandringer. Museum Tusculanums Forlag, København

Thoroddsen, T. 1913-1914. Islands Klima i Oldtiden. Geografisk Tidsskrift, Bind 22, 204-216, København,.

Utterström, G. 1955. Climatic Fluctuations and Population Problems in Early Modern History. Scandinavian economic history review, vol. III, no. 1, 3-47.

Walløe, L. 1982. Pest og folketall 1350-1750. Historisk Tidsskrift, 61, 1-45.

Werenskiold, W. 1924. Klimavekslinger som historisk faktor. Samtiden 1924, 147-158. 
Wigley, T.M.L., Ingram, M.J. \& Farmer, G. 1981 (eds.). Studies in past climates and their impact on Man. Cambridge University Press.

Wishman, E.H. 2007. Var og klima over indre strøk av Østlandet 1781-1790. AmS-Varia 46.

Wishman, E., Frenzel, B. \& Weiss, M.M. (eds.). 1998. Documentary climatic evidence for $1750-1850$ and the fourteenth century. Paläoklimaforschung, Vol. 23. Gustav Fischer Verlag.

Øye, I. 2006. Landbruket i historisk lys. I Knut Helle (red.). Vestlandets historie. Natur og ncering, 76-132. Vigmostad og Bjørke.
Noter

' Dette er Diltheys klassiske skille mellom de humanistiske og naturvitenskapelige fagområdene og er senere blitt videreført og problematisert, men i denne sammenhengen er det tilstrekkelig for å understreke mitt poeng vedrørende de problemene historikere og klimatologer har hatt for å finne en felles plattform for samarbeid.

${ }^{2}$ Det kan vises til en dansk publikasjon: M. Sørensen og M. Fugl Eskjær, Klima og mennesker. Humanistiske perspektiver på klimaforandringer, Museum Tusculanums Forlag, København 2014. Her er det bidrag fra flere humanistiske fag angående hvordan de kan behandle klimautfordringene faglig. 